\title{
LABORATORY RESEARCH OF TOE RESISTANCE BASED ON STATIC PILE LOAD TESTS IN DIFFERENT SCHEMES
}

\author{
Krzysztof ŻARKIEWICZ ${ }^{1}$ \\ The West Pomeranian University of Technology in Szczecin, Szczecin, Poland
}

\begin{abstract}
Transfer of axial force from the head of a pile to the surrounding soil by skin friction and toe resistance is still uncertain. The results of the static pile load test are usually presented as settlement curve. This curve can be divided into two components: skin friction curve and toe resistance curve according to the settlement. Laboratory research of pile load test was carried out in two schemes: with skin friction and without skin friction. The study proved that the toe resistance with and without skin friction is not the same. Skin friction influence on toe resistance due to settlement. This phenomenon is not usually taken into account, but very often has a significant impact on axially applied load transfer. In the paper results of laboratory pile load tests id, different schemes were presented.
\end{abstract}

Keywords: pile load test, settlement, skin friction, laboratory research

\section{INTRODUCTION}

Piles are commonly used in case of not enough stiff soils. To design pile in the economical way we accept the greater settlement, but we also keep in mind that we have to ensure safety. Therefore, the good knowledge of pile-soil cooperation is the most important issue. There is a lot of fields and laboratory research of pile load-settlement relationship behaviour, but there is still a lot of doubts why skin friction and toe resistance which are observed in the field test are different than calculated. Very often bearing capacity of pile is calculated independently of the settlement, but this criterion is insufficient. The possible different ways of skin

1 Corresponding author: West Pomeranian University of Technology Szczecin, Department of Geotechnical Engineering, al. Piastów 50, 70-311 Szczecin, Poland, e-mail: kzarkiewicz@zut.edu.pl, tel.+48914494337 
friction and toe resistance mobilization of the same pile were presented on the Fig. 1. The bearing capacity of the pile is the sum of two components: toe resistance and skin friction (1.1).

$$
N_{g r, 2}=N_{g r, 1}+T_{\infty}
$$

a)

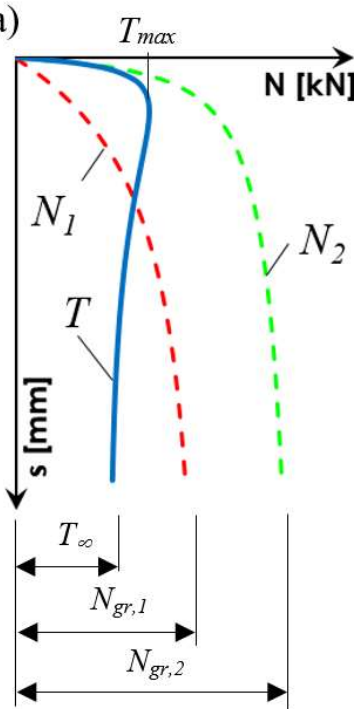

b)

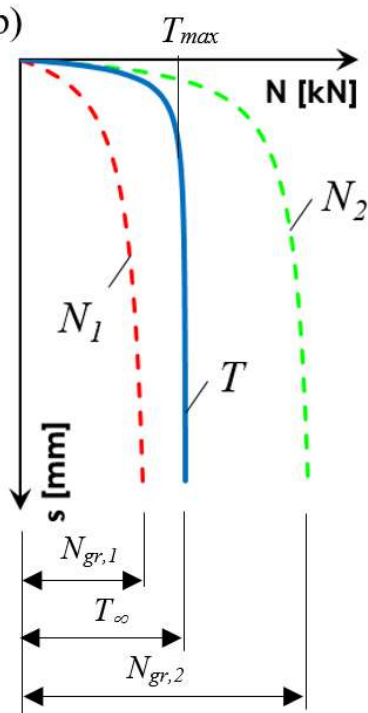

c)

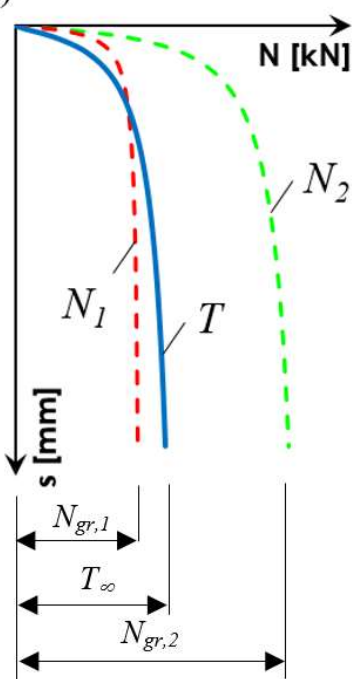

Fig 1. Different toe resistance $N_{l}$ and skin friction $T$ mobilization due to the same values of ultimate skin friction $T_{\infty}$, toe resistance $N_{g r, l}$ and bearing capacity of the pile $N_{g r, 2}$.

a) Skin friction achieves maximum value $T_{\max }$ and then is going to residual value $T_{\infty}$,

b) Skin friction achieve maximum value equals the ultimate value $T_{\max }=T_{\infty}$,

b) Slow skin friction mobilization [13]

Eurocode 7 indicates that the most reliable method of pile load capacity verification is a static pile load test (SPLT). The SPLT allows determining the relationship between the applied load and settlement of the head of the pile. Research in the field with additional measurement equipment allows determining real load distribution along the shaft of the pile, but due to the strong heterogeneity of the soil, it is very difficult to correctly interpret them. It was the reason to carry out laboratory research of pile load test in small scale. Firstly the relationship between the geometry of the pile (H/D) and failure behaviour was checked. The previous research indicated that if the H/D is smaller than 2,5 then failure is similar to the shallow foundation where the soil is extruded on the ground surface. The results of the research were presented in [14]. Current methods of pile load capacity design sometimes lead to different results [9], therefore further study is necessary. 


\section{RESEARCH MODEL DESCRIPTION}

The study was conducted on a laboratory model of the concrete pile which has $7 \mathrm{~cm}$ diameter and $20 \mathrm{~cm}$ long. The laboratory test stand consisted of steel chamber which was filled with non-cohesive soil (medium sand). During laboratory pile load test settlement and applied load was measured. Research is carried out in two schemes:

1. Standard static pile load test, where both skin friction and toe resistance affect load settlement relationship (Fig. 2a)

2. Static pile load tests without skin friction (soil hasn't gotten any contact with the shaft of the piles) (Fig. 2b);

a)
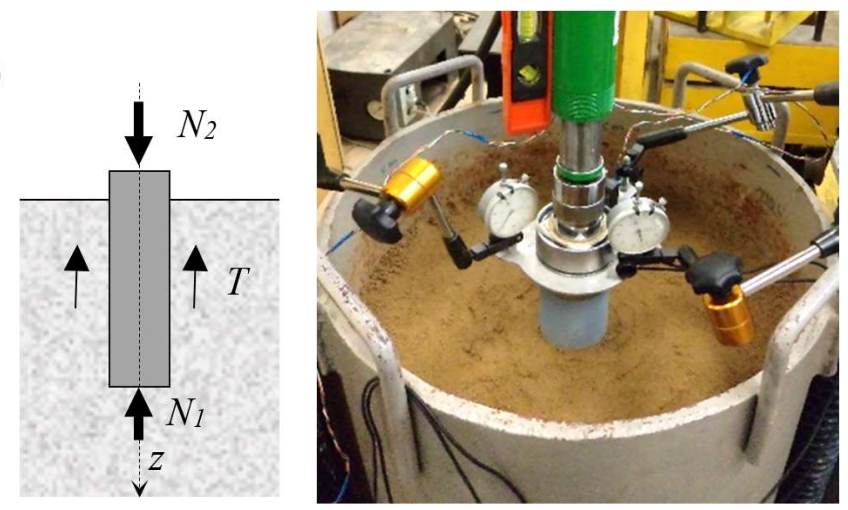

b)
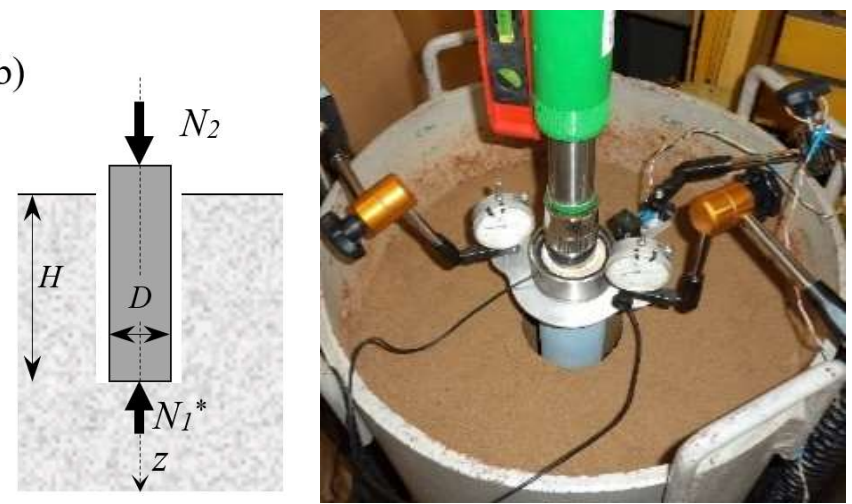

Fig. 2. Schemes of the model pile load test: a) scheme 1 (standard pile load test), b) scheme 2 (pile load test without skin friction)

The used models of piles have surface ratios that do not correspond to the most real piles, but the previous research indicated that soil behaviour because of ultimate strength is similar to the real pile. It was expected small skin friction participation in transferring load from the head of the pile to the surrounding soil, 
so the pile used in laboratory model not to be compared to the real piles. The main aim of the paper is to investigate the effect of skin friction on the toe resistance. According to the Fig. 2a we have equation (2.1),

$$
N_{2}=N_{1}+T
$$

and from the Fig. $2 \mathrm{~b}$ we have equation (2.2).

$$
N_{2}=N_{1}^{*}
$$

The laboratory tests were made for 9 piles in ratio $2.85<\mathrm{H} / \mathrm{D}<6.90$, however, in the presented article, the description is given only for chosen 3 piles.

Piles were investigated in three different $I_{D}$ (index of density) of sand. The sample results of pile 2 are summarised in table 1-2 and also presented on Fig. 3.

Table 1. Findings of pile load test no 2 According to Fig. 2a and Fig. 3.

\begin{tabular}{|c|c|c|c|c|c|c|c|c|c|c|}
\hline$N_{2}$ & {$[\mathrm{kN}]$} & 0,00 & 0,94 & 1,87 & 2,81 & 3,74 & 4,68 & 5,61 & 6,55 & 7,48 \\
\hline$S_{i}$ & {$[\mathrm{~mm}]$} & 0,00 & 0,07 & 0,44 & 1,07 & 1,64 & 2,33 & 3,21 & 4,60 & 7,50 \\
\hline
\end{tabular}

Table 2. Findings of pile load test no 2. According to Fig. $2 b$ and Fig. 3.

\begin{tabular}{|c|c|c|c|c|c|c|c|c|c|c|c|}
\hline$N_{1} *$ & {$[\mathrm{kN}]$} & 0,00 & 1,25 & 1,87 & 2,49 & 3,12 & 3,74 & 4,37 & 4,99 & 5,61 & 6,24 \\
\hline$S_{i}$ & {$[\mathrm{~mm}]$} & 0,00 & 0,17 & 0,55 & 1,18 & 1,84 & 2,62 & 3,57 & 4,70 & 6,43 & 11,45 \\
\hline
\end{tabular}

Toe resistance in scheme 2 is smaller than the applied load in scheme 1. It might be caused by skin friction which did not occur in scheme 1 . When we calculate skin friction based on geostatic stresses according to the shear of the soil we obtain only $0,07 \mathrm{kN}$, but in the laboratory research, we observed difference achieve above $1 \mathrm{kN}$. What is the reason for the discrepancy? To analyse the static pile load tests it is comfortable to use a method which allows describing piles settlement curves by mathematical parameters.

\section{ANALYSIS OF THE RESULTS}

Pile load test results were approximated using Meyer-Kowalow method (M-K) proposed in 2010 [5] and developed by Szmechel [6] and Żarkiewicz [8]. The approximation according to Equation (3.1) [5] allowed describing pile load tests results by three parameters: $C, N_{g r}, \kappa$. These parameters were determined statistically using the least square method of deviations. The curve describes all range of forces which can be applied to the head of the pile. 


$$
s=\frac{C N_{g r}}{\kappa}\left[\left(1-\frac{N}{N_{g r}}\right)^{-\kappa}-1\right]
$$

where:

$\mathrm{C}$ - Settlement curve parameter $[\mathrm{mm} / \mathrm{kN}]$,

$N_{g r}$ - bearing capacity of the pile, when uncontrolled settlement are observed [kN],

$\kappa$ - Dimensionless parameter of settlement curve [-],

$N$ - Applied load [kN],

$s$ - Settlement of the head of the pile [mm].

Table 3. presents results of M-K approximation. It can be noticed that $C$ parameter and $N_{2, g r}, N_{l, g r *}$ decreases according to the reduction of the initial value of soil density. The difference between $N_{2, g r}$ and $N_{l, g r}$ is greater if the soil is more compacted.

Table 3. The result of M-K approximation of three model piles

\begin{tabular}{|c|c|c|c|c|c|}
\hline \multirow{4}{*}{} & \multicolumn{2}{|c|}{ No } & 1 & 2 & 3 \\
\cline { 2 - 6 } & $H$ & {$[\mathrm{~m}]$} & 0,2 & 0,2 & \\
\cline { 2 - 6 } & $D$ & {$[\mathrm{~m}]$} & 0,07 & 0,07 & \\
\cline { 2 - 6 } & $I_{D}$ & {$[\%]$} & $87 \%$ & $63 \%$ & \\
\hline \multirow{4}{*}{ Scheme 2 } & $C_{I} *$ & {$[\mathrm{~mm} / \mathrm{kN}]$} & 0,181 & 0,75 & Scheme 2 \\
\cline { 2 - 6 } & $N_{l, g r} *$ & {$[\mathrm{kN}]$} & 26,3 & 7,41 & \\
\cline { 2 - 7 } & $\kappa_{l} *$ & {$[-]$} & 0,842 & 0,01 & \\
\hline \multirow{3}{*}{ Scheme 1 } & $C_{2}$ & {$[\mathrm{~mm} / \mathrm{kN}]$} & 0,107 & 0,282 & Scheme 1 \\
\cline { 2 - 7 } & $N_{2, g r}$ & {$[\mathrm{kN}]$} & 36,08 & 8,78 & \\
\cline { 2 - 7 } & $\kappa_{2}$ & {$[-]$} & 0,138 & 0,447 & \\
\hline
\end{tabular}

The last research on a model instrumented pile of the same pile geometry which was carried out by Żarkiewicz [13] allowed to determine the formulae on $C_{l}$, $N_{g r, 1}, \kappa_{1}$ based on $C_{2}, N_{g r, 2}, \kappa_{2}$ which were obtained from static pile load test (3.2-3.4) [13]. The presented formulas (3.2-3.4) was determined based on 10 instrumented piles in laboratory tests. The formulas were determined using the method of the least sum of squares relative to measured values. Compatibility was achieved for parameter $C_{l}, N_{g r, l}, \kappa_{l}$ equals $R^{2}=0.97,0.98,0.53$ respectively. More about statistic calculation of proposed formula was described in [13].

The following formulas allow determining toe resistance curve. The density of the soil is included in the settlement curve parameters. In this way, it is possible to determine toe resistance in scheme 1, when skin friction was influenced on toe resistance. 


$$
\begin{gathered}
C_{1}=C_{2}\left(0,368 \kappa_{2}+1\right)^{2} \\
N_{g r, 1}=\frac{C_{2}}{C_{1}} N_{g r, 2}\left[1+0,437\left(\frac{H}{D}\right)^{1 / 3} \kappa_{2}\right] \\
\kappa_{1}=0,8276 \kappa_{2}
\end{gathered}
$$

The calculated values of toe resistance mobilization were presented in Table 4 .

Table 4. Calculated M-K parameters corresponding to the toe resistance

\begin{tabular}{|c|c|c|c|c|}
\hline \multicolumn{2}{|c|}{ No } & 1 & 2 & 3 \\
\hline$C_{l}$ & {$[\mathrm{~mm} / \mathrm{kN}]$} & 0,119 & 0,386 & 0,850 \\
\hline$N_{l, g r}$ & {$[\mathrm{kN}]$} & 35,36 & 8,19 & 4,48 \\
\hline$\square_{I}$ & {$[-]$} & 0,115 & 0,372 & 0,312 \\
\hline
\end{tabular}

Comparison of toe resistance obtained from scheme 2 (without skin friction) and toe resistance calculated using Żarkiewicz formulae based on static pile load test results from scheme 1 is presented in Figures 3-5.

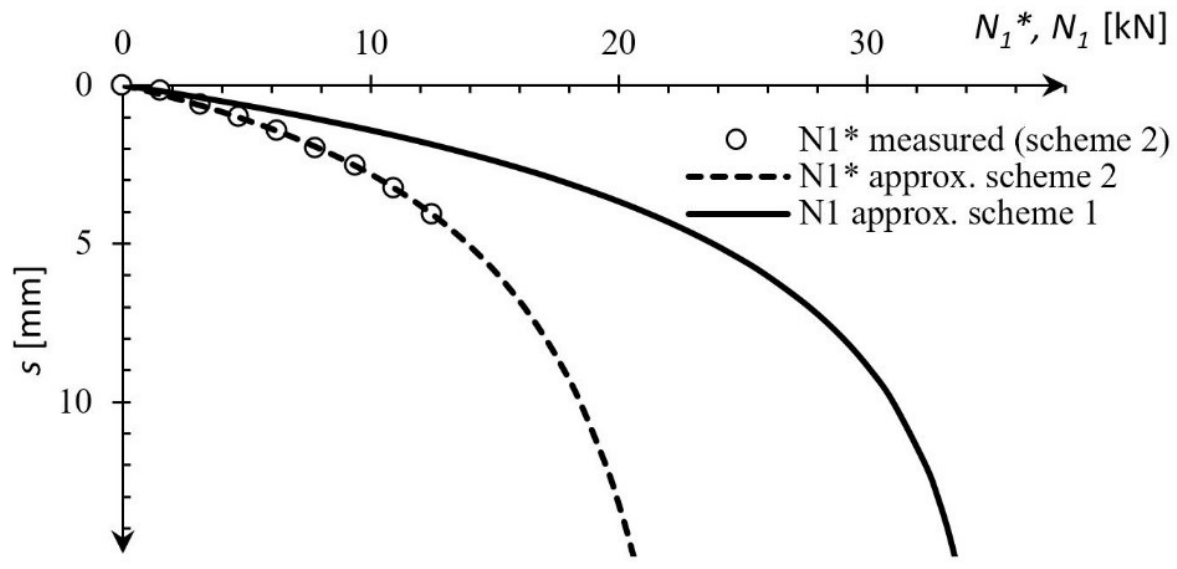

Fig. 3. Comparison of toe resistant without skin friction $(\mathrm{N} 1 *$ scheme 1 and $\mathrm{N} 1 *$ measured) and with skin friction (N1 scheme 1). Pile 1.

The calculation of toe resistance in scheme 1 was higher than the one measured in scheme 2 . In scheme 2 were also higher values of $C_{l}$ parameters. The ultimate value of toe resistance pile 3 decreases, because this pile was embedded into the least densified sand. In this way firstly skin friction cause hardening of the soil, but finally reduced the ultimate toe resistance. 


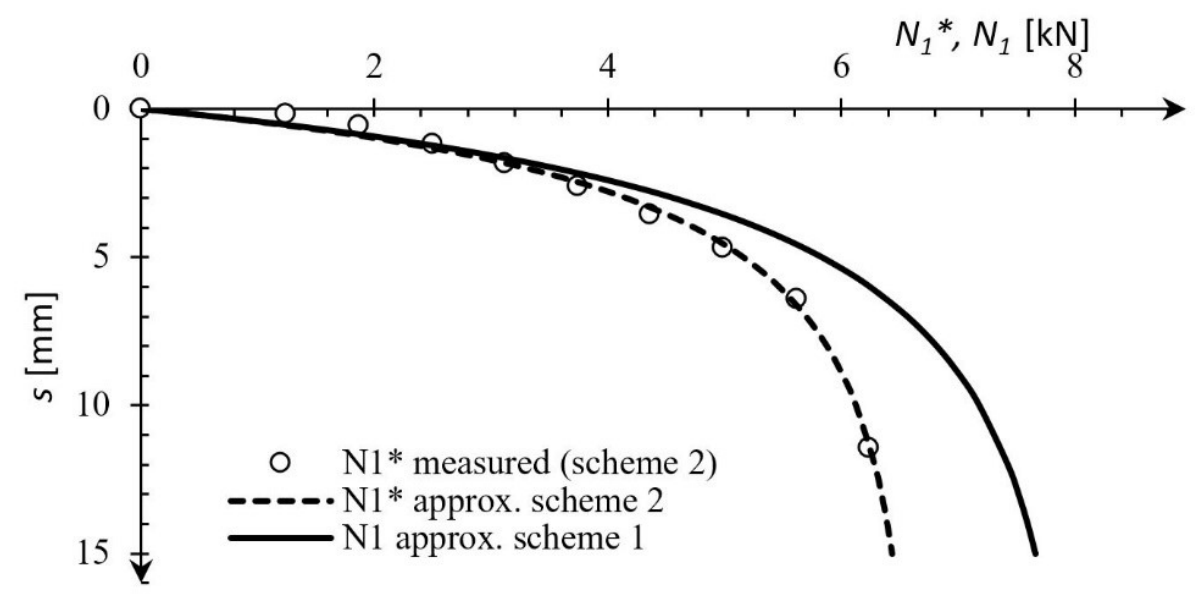

Fig. 4. Comparison of toe resistant without skin friction $(\mathrm{N} 1 *$ scheme 1 and $\mathrm{N} 1 *$ measured) and with skin friction (N1 scheme 1). Pile 2.

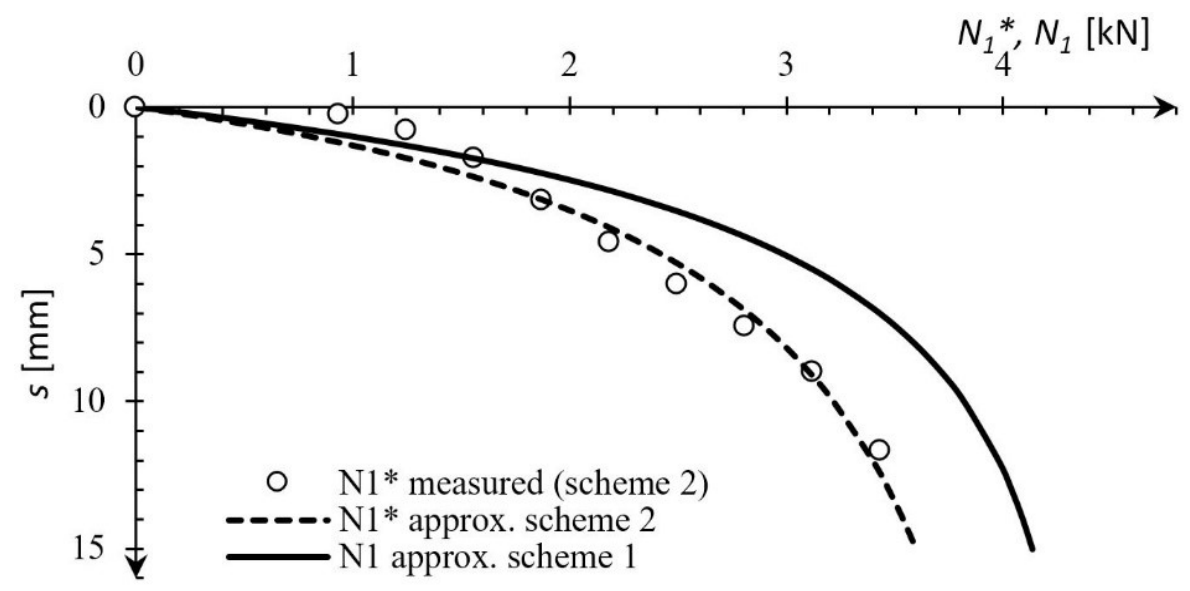

Fig. 5. Comparison of toe resistant without skin friction $(\mathrm{N} 1 *$ scheme 1 and $\mathrm{N} 1 *$ measured) and with skin friction (N1 scheme 1). Pile 3.

Skin friction in cohesionless soil in practice is often calculated generally according to Mohr-Coulomb strength criterion based on vertical stress, lateral pressure coefficient and angle of friction at the pile and soil interface. This calculation does not include the possibility of horizontal stresses changes during transfer load applied at the head of the pile. Study of $[1,3,10]$ proved that unit skin resistance can exceed vertical stress values. This may explain high skin resistance. In the figures 3-5 toe resistance without skin friction is smaller than the toe resistance in standard static pile load test, so it can be argued that skin friction which sometimes achieves high values has an influence on toe resistance in 
scheme 1. The phenomena were also observed by Kamal, Arab, Dif [4] and Ivšić, Bačić, Librić [2]. They stated that stresses under the toe of the pile can induce an increase of horizontal stresses surrounding the shaft of the pile near to the toe and cause increase of skin friction and toe resistance. The opposite effect may occur due to contractive soil under the toe of the pile where skin friction may reduce ultimate toe resistance. These phenomena can be caused by the initial state of the soil. Coulomb-Mohr parameters are usually determined in a limit state of stress, but the deformation behaviour according to small strain may be different. It was described by steady state line which is the failure line developed by Sawicki and Świdziński $[11,12]$. The state of the soil depends on not only on Coulomb-Mohr parameters, the density of soil, and modulus but also from mean effective stresses. The volume of soil during shear decrease or increase due to the initial state of parameters and state of effective stress. The stresses can be changed due to transfer shaft resistance to the surrounding soil so it may cause the changes in toe resistance. In summarise, it can be told that toe resistance and skin friction are not independent, and they shouldn't be calculated separately.

\section{CONCLUSIONS}

The test results analysis leads to the following conclusions:

1. Laboratory research of static pile load test in small scale was carried out. A study was conducted in two schemes to find out if toe resistance mobilization is completely independent of skin friction.

2. Analysis using formulae derived from previous research on instrumented piles allowed determining toe resistance in standard static pile load test when the axial load is transferred to the surrounding soil by skin friction and toe resistance.

3. Toe resistance without skin friction was different from the one with the participation of skin friction. It indicates the strong relationship between skin friction and toe resistance.

4. The last research of Kamal, Arab, Dif [4] and Ivšić, Bačić, Librić [2] and Żarkiewicz, Meyer [7] indicate that skin friction and toe resistance relationship near to the toe of the pile may significantly influence on pile loadsettlement behaviour.

5. The program of further study is to investigate the relationship between skin friction and toe resistance, determine horizontal stresses around the shaft of the pile during the static pile load test, and describe the interface in fluent and initial state of soil conditions on skin friction mobilizing. This is the main goal in developing pile load capacity design methods. 


\section{REFERENCES}

1. Han F., Salgado R., Prezzi M., Lim J.: Shaft and base resistance of nondisplacement piles in sand. Computers and Geotechnics, vol.83, 2017, P:184197.

2. Ivšić T., Bačić M., Librić L.: Estimation of bored pile capacity and settlement in soft soils. Gradjevinar, vol.65, 2013, P:901-918.

3. Lehane B.M. et al.: Mechanism of shaft friction in sand from instrumented pile tests. vol.119, 2016, P:19-35.

4. Kamal Z.A., Arab M.G., Dif A.: Analysis of The arching phenomenon of bored piles in sand. Alexandria Engineering Journal, vol.55, 2016, P:26392645.

5. Meyer Z., Kowalów M.: Model krzywej aproksymujacej wyniki testów statycznych pali. Inżynieria Morska i Geotechnika. nr 3/2010.

6. Meyer Z., Szmechel G.: Analiza możliwości analitycznej aproksymacji krzywej obciązenie-osiadanie dla testów statycznych pali żelbetowych w gruntach sypkich. Inżynieria Morska i Geotechnika. nr 4/2010.

7. Meyer Z, Żarkiewicz K.: Mechanizm formowania się oporu pobocznicy przy podstawie pala określony na podstawie badań laboratoryjnych. Inżynieria i Bududownictwo. 5/2017 vol.73, P:263-265.

8. Meyer Z., Żarkiewicz K.: Analiza mobilizacji oporu pobocznicy i podstawy pala na podstawie interpretacji badań modelowych. Inżynieria Morska i Geotechnika, nr 3/2015, P:350-354.

9. Nguyen G.: Differences in Determination of Bored Pile Compressive Resistance in Slovakia and Poland. Procedia Engineering, vol.153, 2016 P:513-518.

10. Rollins K.M. et al.: Drilled Shaft Side Friction in Gravelly Soils. Journal of Geotechnical and Geoenvironmental Engineering, 2005 P:987-1003.

11. Sawicki A, Świdziński W. Drained against undrained behaviour of sand. Arch Hydroengineering Environ Mech. 2007;54(3):207-22.

12. Sawicki A.: Zarys mechaniki gruntów sypkich. Gdańsk: Wydawnictwo IBW PAN; 2012. 214 p.

13. Żarkiewicz K.: Analiza formowania się oporu pobocznicy pala $w$ gruntach niespoistych na podstawie modelowych badań laboratoryjnych. Rozprawa doktorska. Zachodniopomorski Uniwersytet Technologiczny w Szczecinie. 2017.

14. Żarkiewicz K, Meyer Z.: Nowe spojrzenie na wspótpracę pala z gruntem $w$ świetle badań laboratoryjnych. Wiadomości Projektanta Budownictwa. Warszawa: Izba Projektowania Budowlanego; 5/2016. 


\section{BADANIA LABORATORYJNE OPORU POD PODSTAWĄ PALA NA PODSTAWIE WYNIKÓW PRÓBNEGO OBCIĄŻENIA STATYCZNEGO PALA PRZEPROWADZONYCH W RÓŻNYCH SHEMATACH}

\section{Streszczenie}

Przekazywanie pionowej siły osiowej przyłożonej w głowicy pala na otaczające podłoże gruntowe jest zagadnieniem wciąż nierozwiązanym i w wielu przypadkach budzącym wiele wątpliwości. Wynik próbnego obciążenia statycznego są zwykle przedstawiane na wykresie w postaci krzywej osiadania pala. Krzywa osiadania może być podzielona na dwie składowe krzywe: krzywą oporu pobocznicy i krzywą oporu podstawy pala w stosunku do osiadania głowicy pala. Badania laboratoryjne próbnych obciążeń statycznych zostały przeprowadzone na palach modelowych, w dwóch schematach obciążenia: $z$ udziałem pobocznicy i bez udziału pobocznicy w przekazywaniu obciążenia przyłożonego w głowicy pala. Wyniki badań wskazują, że opór podstawy pala jest różny w zależności od schematu. W związku z tym istnieje zależność oporu podstawy i pobocznicy pala. W artykule przedstawiono wyniki badań laboratoryjnych wraz $\mathrm{z}$ interpretacją.

Słowa kluczowe: próbne obciążenie statyczne pala, osiadanie, opór pobocznicy, badania laboratoryjne

Editor received the manuscript: 26.02.2018 